\title{
Screening of spiro-substituted thiopyrano[2,3-d]thiazoles for their cytotoxic action on tumor cells
}

\author{
N. I. Zelisko ${ }^{1}$, N. S. Finiuk ${ }^{2}$, V. M. Shvets ${ }^{3}$, Yu. O. Medvid ${ }^{1}$, \\ R. S. Stoika ${ }^{2}$, R. B. Lesyk ${ }^{1}$ \\ ${ }^{1}$ Danylo Halytsky Lviv National Medical University \\ 69, Pekarska Str., Lviv, Ukraine, 79010 \\ 2 Institute of Cell Biology, NAS of Ukraine \\ 14/16, Drahomanov Str., Lviv, Ukraine, 79005 \\ ${ }^{3}$ Zaporizhia State Medical University, \\ Mayakovsky avenue 26, Zaporizhzhia, Ukraine, 69035 \\ dr_r_lesyk@org.lviv.net,roman.lesyk@gmail.com
}

\begin{abstract}
Aim. To evaluate the in vitro cytotoxicity of novel spiro-substituted thiopyrano[2,3-d]thiazoles towards tumor cells of different tissue origin. Methods. Organic synthesis; spectral methods; MTT test, statistical analysis. Results. In vitro screening of the cytotoxic activity of the 5'-carboxy-7'-aryl-1-aryl-3',7'-dihydro-2H,2 ' $H, 5 H$-spiro[pyrolidin-3,6'-thiopyrano[2,3- $d$ ] thiazol]-2,2',5-triones and $N$-(4-chlorophenyl)-2-[1-(4-chlorophenyl)-2,5-dioxopyrrolidin-3ylidene]-acetamide was performed using various cancer cell lines (Jurkat human acute T-cell leukemia cell line, MCF-7 human breast adenocarcinoma cell line, Skov3 human ovarian carcinoma cells line, SK-Mel-28 human melanoma cells line, and SW-1573 human non-smallcell lung cancer cell line). The tested compounds possessed different cytotoxic action towards the studied tumor cells. Leukemia cells appeared to be more sensitive for the studied derivatives. The cytotoxic effect of the compound 2 towards Jurkat cells was shown to be dose- and time-dependent $(3,6,24,48$ and $72 \mathrm{~h})$. This compound demonstrated the cytotoxic action towards Jurkat cells as soon as in $6 \mathrm{~h}$ after its addition to the cultured cells $\left(\mathrm{IC}_{50}=66 \mu \mathrm{M}\right)$, and its toxicity towards these cells was more prominent after $24 \mathrm{~h}$ treatment $\left(\mathrm{IC}_{50}=40 \mu \mathrm{M}\right)$. Conclusions. The panel of thiopyrano[2,3- $d]$ thiazole derivatives was synthesized and screened for their cytotoxic activity in vitro towards tumor cells of different tissue origin. The compound 2 was found to be the most active agent with selectivity for the leukemia cells. This compound inhibits growth of the human acute T-cell leukemia cells of Jurkat line $\left(\mathrm{IC}_{50}=33.5 \mu \mathrm{M}\right)$ and possesses relatively low toxicity towards the pseudo-normal mammalian cells.
\end{abstract}

Ke y w or d s: thiopyrano[2,3-d] thiazoles, cytotoxic activity

C 2017 N. I. Zelisko et al.; Published by the Institute of Molecular Biology and Genetics, NAS of Ukraine on behalf of Biopolymers and Cell. This is an Open Access article distributed under the terms of the Creative Commons Attribution License (http://creativecommons.org/licenses/by/4.0/), which permits unrestricted reuse, distribution, and reproduction in any medium, provided the original work is properly cited 


\section{Introduction}

Chemotherapy is one of the most effective ways of treating cancer patients. Conventional anticancer drug discovery and development have been focused on the cytotoxic agents. The drug discovery paradigms selected agents that had significant cytostatic or cytotoxic activity towards tumor cell lines in vitro and caused tumor regression in vivo [1]. However, their application in cancer treatment is accompanied by frequent non-addressed actions leading to numerous negative side effects in the organism [2]. Due to these effects, they demonstrate toxicity toward different normal cells of tissues and organs, including the bone marrow cells, mucous layer of the intestine, reproduction glands, and hair follicles.

4-Thiazolidinones and related heterocycles have been demonstrated to be a perspective source of the innovative anticancer agents $[3,4]$. In the previous studies, we identified a large group of substances with high anticancer potential and low toxicity $[5,6]$. According to the obtained data [6], most of the studied substances influenced cancer cell lines. 5-Ene-4thiazolidinones were identified to possess the highest antitumor activity towards leukemia cells and induction of apoptosis in the mammalian leukemia cells [7]. However, the mechanisms of the anticancer activity of these compounds have not been studied yet.

Previously it has been reported that PPAR $\gamma$ agonists, namely 4-thazolidinone derivatives, have a therapeutic potential in treatment of the inflammation and some cancers. This scientific assumption was successfully proved [8]. Among 4-thiazolidinones, there were also identified the effective inhibitors of the anti- apoptotic proteins $\mathrm{Bcl}-\mathrm{XL}$ and $\mathrm{BH} 3$ interactions [9], the inhibitors of the interaction between TNF $\alpha$ and the receptor TNFRc-1 [10], and the inhibitors of translation initiation [11]. A significant influence on the above mentioned pathogenic mechanisms of tumor growth determines perspectives of 4-thiazolidinones as potential anticancer drugs.

The studied thiopyrano[2,3- $d]$ thiazoles [12-14] keep the pharmacological profile of 5-ene-4-thiazolidinones and create new possibilities for biological activities. Among the described thiopyrano[2,3- $d]$ thiazole derivatives, there are anticancer [15-19], antitrypanosomal [20], antimycobacterial, antibacterial, and antifungal agents [21].

The main aim of this study was to measure the toxic effect in vitro of novel spiro-substituted thiopyrano[2,3- $d]$ thiazoles towards tumor cells of different tissue origin.

\section{Materials and Methods}

All chemicals used in the study were of the analytical grade and commercially available. All reagents and solvents were used without further purification and drying.

\section{Chemistry}

Series of rel-(5'R, $\left.6^{\prime} R, 7^{\prime} R\right)-5^{\prime}$-carboxy-7'-aryl1 - ary $1-3$ ', 7' - dihydro-2 H, 2' $H, 5 H$ spiro[pyrolidin-3,6'-thiopyrano[2,3-d] thiazol]2,2',5-triones (1a-e) for screening cytotoxicity were synthesized via hetero-Diels-Alder reaction (Scheme 1) starting with trans-aconitic acid, corresponding aromatic amine and appropriate 5-arylidene-4-thioxo-2-thiazolidinone in the presence of the catalytic amount of hydroquinone (2-3 $\mathrm{mg}$ ) for preventing polymerization processes, as it was described in our previ- 

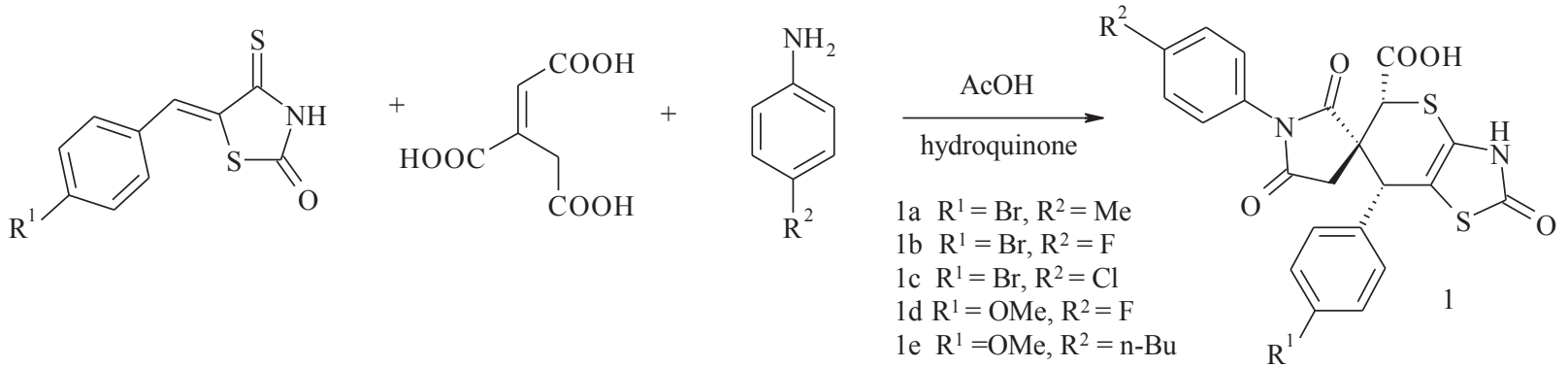

Scheme 1. General synthetic path used for getting rel-(5'R, $\left.6^{\prime} R, 7^{\prime} R\right)-5^{\prime}$-carboxy-7'-aryl-1-aryl-3', $7^{\prime}$-dihydro$2 H, 2^{\prime} H, 5 H$-spiro[pyrolidin-3,6'-thiopyrano[2,3-d] thiazol]-2,2',5-triones.

ous work [22]. The 5-arylidene-4-thioxo-2-thiazolidinones were synthesized via Knoevenagel condensation of 4-thioxo-2-thiazolidinone with the aromatic aldehydes [23].

Notably, we have identified 2-(2,5-dioxo1 -arylpyrrolidin-3-ylidene)- $N$-aryl-acetamides as minor products of the mentioned one-pot three-component reaction. These compounds were easily removed during the recrystallization of crude products. We have found that the mentioned 2-(2,5-dioxo-1-arylpyrrolidin3 -ylidene)- $N$-aryl-acetamides are formed with good yields via the interaction of trans-aconitic acid and appropriate aniline in the ratio 1:2. Thus, N-(4-chlorophenyl)-2-[1-(4-chlorophenyl)-2,5-dioxopyrrolidin-3-ylidene]-acetamide 2 was synthesized in the glacial acetic acid medium using 4-chloroaniline as amino component (Scheme 2).
Screening of cytotoxic activity. Materials $10 \mathrm{mM}$ stock solution of synthesized compounds was prepared in the dimethyl sulfoxide (DMSO, Sigma-Aldrich, USA), and additionally dissolved in culture medium prior to its addition to the cell culture. 3-(4,5-Dimethylthiazol-2-yl)-2,5-diphenyl-tetrazolium bromide (MTT) was $99.5 \%$ pure. Cell culture medium DMEM was obtained from Sigma-Aldrich (USA), and RPMI - from APP (Austria). Fetal bovine serum (FBS) was obtained from APP (Austria), and Doxorubicin - from Pharmachemie B.V. (the Netherlands).

\section{Cell cultures}

Human acute T-cell leukemia cells of Jurkat line, human breast adenocarcinoma cells of MCF-7 line, human ovarian carcinoma cells of Skov3 line, human melanoma cells of SK-<smiles>Nc1ccc(Cl)cc1</smiles>

Scheme 2. Synthesis of $N$-(4-chlorophenyl)-2-[1-(4-chlorophenyl)-2,5-dioxopyrrolidin-3-ylidene]-acetamide. 
Mel-28 line, human non-small-cell lung cancer cells of SW-1573 line, transformed mouse fibroblasts of L929 line, human embryonic kidney cells of HEK293 line were obtained from Cell culture collection at R.E. Kavetsky Institute of Experimental Pathology, Oncology and Radiology (Kyiv, Ukraine). Cells were grown in the RPMI or DME culture medium supplemented with $10 \%$ fetal bovine serum. Cells were cultivated in the $\mathrm{CO}_{2}$-thermostate at $37{ }^{\circ} \mathrm{C}$ in atmosphere of $95 \%$ air and $5 \%$ $\mathrm{CO}_{2}$ at $100 \%$ humidity.

\section{Cytotoxicity assay}

Cytotoxic activity of the synthesized compounds and doxorubicin used as a reference drug control towards cancer cell lines cultured in vitro was measured by the MTT test [24]. Tumor cells were seeded for $24 \mathrm{~h}$ in 96-well microtiter plates at a concentration of 2,000 of substrate-dependent cells/well or 10,000 of suspension cells/well in $100 \mu \mathrm{L}$. After that, cells were treated for $72 \mathrm{~h}$ with various additions of the synthesized compounds $(0 ; 1 ; 10 ; 50 ; 100 \mu \mathrm{M})$. The MTT reagent, which is converted by mitochondrial dehydrogenases to dark blue, water insoluble MTT formazan, was used to measure the vitality of cells according to the manufacturer's protocol (Sigma-Aldrich, USA). The $\mathrm{IC}_{50}$ of tested compounds was calculated as a lethal concentration of drug decreasing cell vitality by $50 \%$ in comparison with drug-free culture medium.

\section{Statistical analysis}

All data are presented as the mean \pm standart deviation (SD). Results were analyzed and illustrated with GraphPad Prism (version 6;
GraphPad Software, San Diego, CA). Statistical analyses were performed using two-way ANOVA with Bonferroni post-tests (tumor growth). P-value of $<0.05$ was considered as statistically significant.

\section{Results and Discussion}

\section{Measuring of cytotoxic activity}

In vitro screening of cytotoxic activity of the synthesized compounds towards various tumor cell lines (human acute T-cell leukemia cells of Jurkat line, human breast adenocarcinoma cells of MCF-7 line, human ovarian carcinoma cells of Skov3 line, human melanoma cells of SK-Mel-28 lines, and human non-small-cell lung cancer cells of SW-1573 line) was performed using the MTT assay. The tested compounds were added to cultured cells in different final concentrations $(0-100 \mu \mathrm{M})$, and then the cells were treated for $72 \mathrm{~h}$ (Fig. 1). The $\mathrm{IC}_{50}$ was calculated and used while comparing the values of the cytotoxic effect.

The tested compounds were found to possess different cytotoxic action towards human tumor cells of various tissue origin. The tumor cells of epithelial origin (MCF-7, Skov3, SKMel-28 and SW-1573 lines) were relatively resistant to the action of compounds 1a-e, $\mathbf{2}$ used in concentrations up to $100 \mu \mathrm{M}$ (Fig. 1).

The anticancer cytotoxic effect in vitro of the compounds $\mathbf{1 a - e ,} \mathbf{2}$ was also studied using human acute leukemia T-cells of Jurkat line. The compound $\mathbf{2}$ possessed cytotoxic activity towards Jurkat cells with the $\mathrm{IC}_{50}=33.5 \mu \mathrm{M}$ (Fig. 2).

Thus, the cytotoxic activity of synthesized compounds 1a-e, 2 seems to depend on the targeted tumor cell line, although the leukemia 

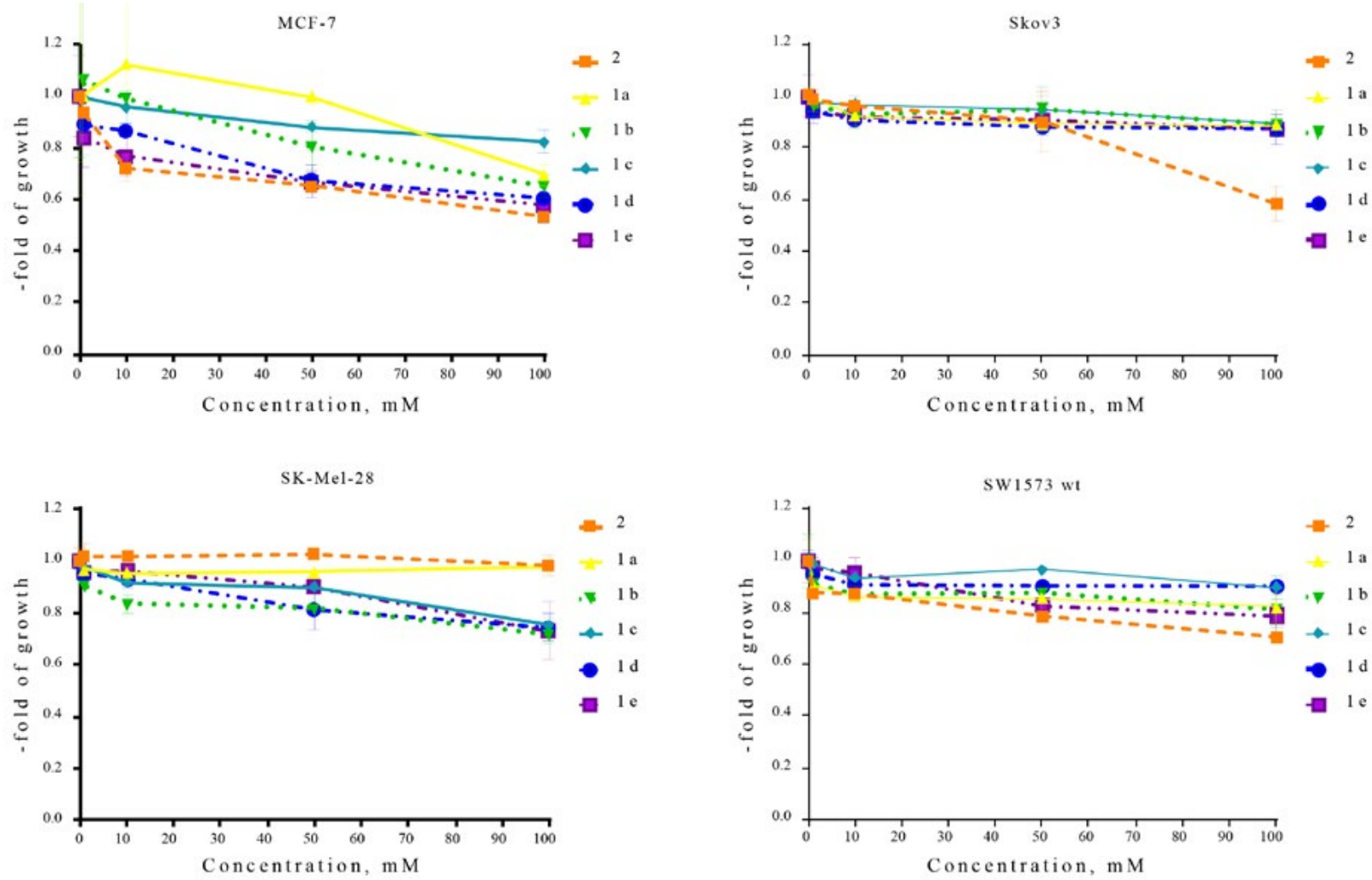

Fig. 1. Results of testing cytotoxicity of compounds towards different tumor cell lines. After a total time of experiment (72 h), cytotoxic effect was measured by the MTT assay.

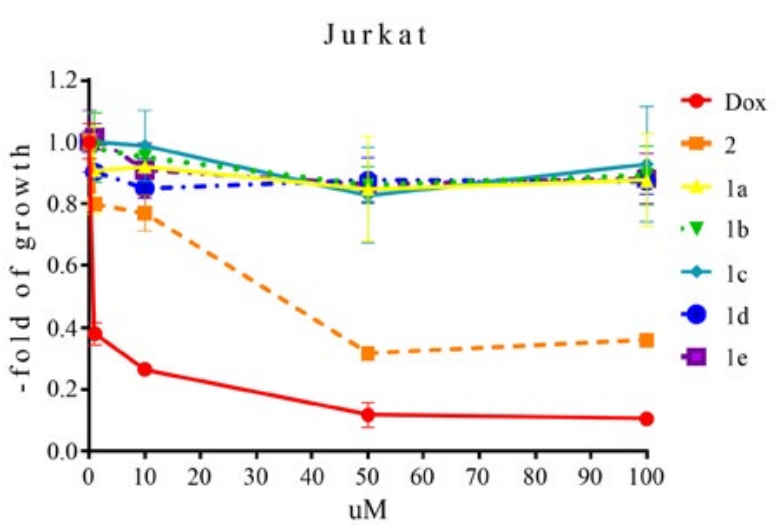

Fig. 2. Results of testing cytotoxicity of compounds towards human acute T-cell leukemia cells of Jurkat line. After a total time of experiment $(72 \mathrm{~h})$ cytotoxic effect was measured by the MTT assay. cells appeared to be the most sensitive to the action of studied derivatives.

Most of chemotherapeutic drugs demonstrate toxicity toward normal cells of tissues and organs, namely the bone marrow cells, cells of mucous layer of the intestine, reproduction glands, and hair follicles [25]. We have measured the cytotoxic effect of the compounds under study towards non-tumor cells, such as transformed mouse fibroblasts of L929 line and pseudo-normal human embryonic kidney cells of HEK293 line (Fig. 3). There was no significant cytotoxic effect of used compounds towards HEK293 and L929 cells. Thus, one could suggest the lack of general 

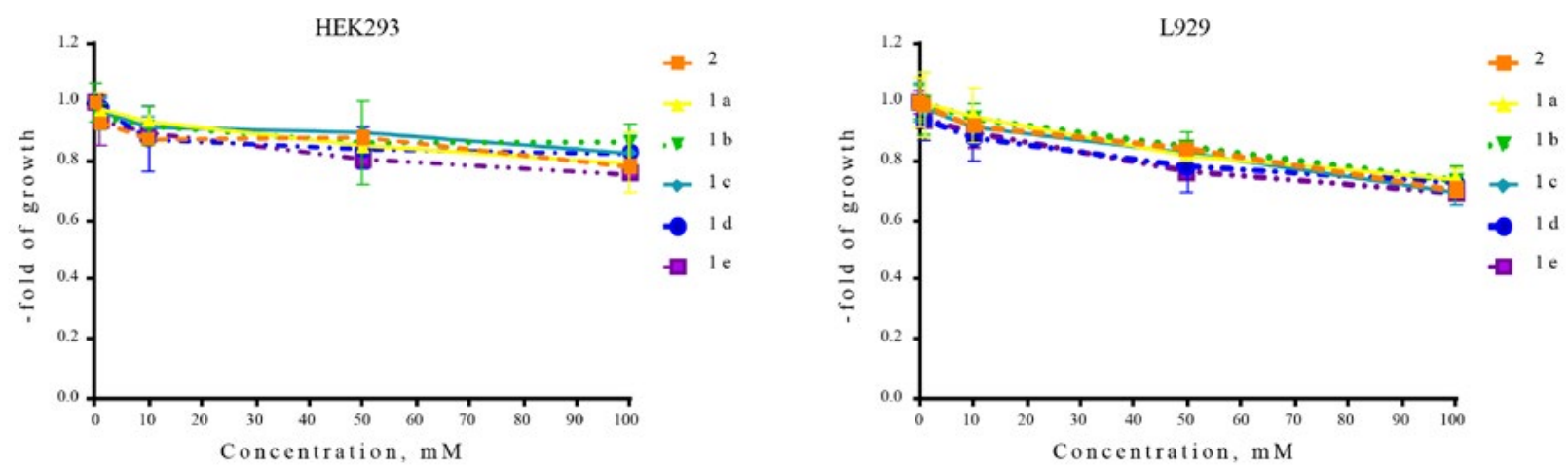

Fig. 3. Results of testing cytotoxicity of compounds towards non-tumor mammalian cells. After a total time of experiment $(72 \mathrm{~h})$ cytotoxic effect was measured by the MTT assay.

toxicity of novel synthetic compounds towards normal cells of tissues and organs.

We found that the cytotoxic effect of compound $\mathbf{2}$ towards human acute T-cell leukemia cells of Jurkat line was dose- and time-dependent $(3,6,24,48$ and 72 h). Compound 2 showed such effect as soon as in $6 \mathrm{~h}$ after starting cell treatment $\left(\mathrm{IC}_{50}=66 \mu \mathrm{M}\right)$, whereas its toxicity towards Jurkat cells was more prominent after $24 \mathrm{~h}$ treatment $\left(\mathrm{IC}_{50}=40 \mu \mathrm{M}\right)$ (Fig. 4).

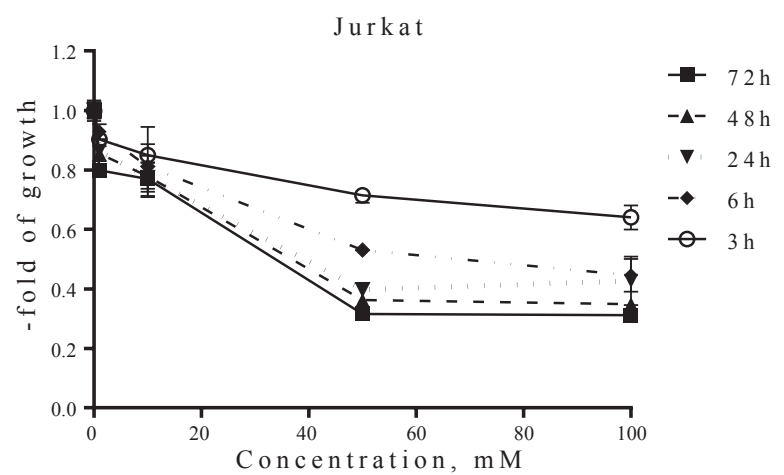

Fig. 4. Exposure time-dependency of compound 2 cytotoxicity. Pulsing experiments were performed using human acute T-cell leukemia cells of Jurkat line treated for 3, 6, 24, 48 and $72 \mathrm{~h}$ with compound 2. Cytotoxic action was determined using MTT assay.

\section{Conclusion}

Novel spiro-substituted thiopyrano[2,3- $d]$ thiazole derivatives were synthesized and tested for their cytotoxic activity towards human tumor cells in vitro. Generally, they possessed low toxicity towards tumor cells. Compound 2 was found to be the most cytotoxic agent specifically towards the human acute T-cell leukemia cells of Jurkat line $\left(\mathrm{IC}_{50}=33.5 \mu \mathrm{M}\right)$. A low toxicity of this compound towards the pseudo-normal human embryonic kidney cells of HEK293 line should be noted.

\section{Acknowledgement}

The publication contains the results of studies conducted by President's of Ukraine grant for competitive projects F-63 of the State Fund for Fundamental Research. The investigation was also supported by Cedars Sinai Medical Center's International Research and Innovation in Medicine Program, the Association for Regional Cooperation in the Fields of Health, Science and Technology (RECOOP HST Association) and the participating Cedars Sinai Medical Center - RECOOP Research Centers (CRRC). 


\section{REFERENCES}

1. Michael CP, Donald CD, Carl EF. The Chemotherapy Source Book. Philadelphia: Walters Kluwer. Lippincott Williams \& Wilkins. 2012; 248p.

2. DeVita, Vincent T. et al, eds. Cancer: Principles and Practice of Oncology. 6th ed. Philadelphia, PA: Lippincott, Williams \& Wilkins, 2001.

3. Chumak VV, Fil MR, Panchuk RR, Zimenkovsky BS, Havrylyuk DY, Lesyk RB, et al. Study of antineoplastic action of novel isomeric derivatives of 4-thiazolidinone. Ukr Biochem J. 2014;86:96-105.

4. Crascì L, Vicini P, Incerti $M$, Cardile V, Avondo $S$, Panico A. 2-Benzisothiazolylimino-5-benzylidene4-thiazolidinones as protective agents against cartilage destruction. Bioorg Med Chem. 2015;23(7):1551-1556.

5. Havrylyuk D, Zimenkovsky B, Vasylenko O, Gzella $A$, Lesyk $R$. Synthesis of new 4-thiazolidinone, pyrazoline, and isatin-based conjugates with promising antitumor activity. $J$ Med Chem. 2012;55:86308641.

6. Havrylyuk D, Zimenkovsky B, Karpenko O, Grellier $P$, Lesyk $R$. Synthesis of pyrazoline-thiazolidinone hybrids with trypanocidal activity. Eur J Med Chem. 2014;85:245-254.

7. Senkiv J, Finiuk N, Kaminskyy N, Havrylyuk D, Wojtyra M, Kril I, Gzella A, Stoika R, Lesyk R. 5-Ene-4-thiazolidinones induce apoptosis in mammalian leukemia cells. Eur $J$ Med Chem. 2016;117:33-46.

8. Atamanyuk D, Zimenkovsky B, Atamanyuk V, Lesyk $R$. 5-Ethoxymethylidene-4-thioxo-2-thiazolidinone as versatile building block for novel biorelevant small molecules with thiopyrano[2,3-d][1,3] thiazole core. Synth Commun. 2014;44(2):237-244.

9. Chen S, Chen L, Le NT, Zhao C, Sidduri A, Lou JP, Michoud C, Portland L, Jackson N, Liu JJ, Konzelmann $F$, Chi F, Tovar C, Xiang $Q$, Chen $Y$, Wen $Y$, Vassilev LT. Synthesis and activity of quinolinylmethylene-thiazolinones as potent and selective cyclin-dependent kinase 1 inhibitors. Bioorg Med Chem Lett. 2007;17(8):2134-2138.

10. Carter PH, Scherle PA, Muckelbauer JA, Voss ME, Liu RQ, Thompson LA, Tebben AJ, Solomon KA,
Lo YC, Li Z, Strzemienski P, Yang G, Falahatpisheh $N, X u M, W u Z$, Farrow $N A$, Ramnarayan $K$, Wang J, Rideout D, Yalamoori V, Domaille P, Underwood DJ, Trzaskos JM, Friedman SM, Newton $R C$, Decicco $C P$. Photochemically enhanced binding of small molecules to the tumor necrosis factor receptor- 1 inhibits the binding of TNF- $\alpha$. PNAS. 2001;98(21):11879-11884.

11. Zhou H, Wu S, Zhai S, Liu A, Sun Y, Li R, Zhang Y, Ekins S, Swaan PW, Fang B, Zhang B, Yan B. Design, synthesis, cytoselective toxicity, structureactivity relationships, and pharmacophore of thiazolidinone derivatives targeting drug-resistant lung cancer cells. J Med Chem. 2008;51(5):1242-1251.

12. Zelisko N, Atamanyuk D, Vasylenko O, Bryhas A, Matiychuk V, Gzella A, Lesyk R. Crotonic, cynnamic, and propiolic acids motifs in the synthesis of thiopyrano[2,3-d][1,3]thiazoles via hetero-DielsAlder reaction and related tandem processes. Tetrahedron. 2014;70:720-729.

13. Zelisko N, Atamanyuk D, Ostapiuk Y, Bryhas A, Matiychuk V, Gzella A, Lesyk R. Synthesis of fused thiopyrano [2, 3-d][1,3] thiazoles via hetero-DielsAlder reaction related tandem and domino processes. Tetrahedron. 2015;71:9501-9508.

14. Kowiel M, Zelisko N, Atamanyuk D, Lesyk R, Gzella $A K$. 6-Ethoxycarbonyl-7-(2-hydroxy-3,5-dibromophenyl)-2-oxo- 2,3,5,6- tetrahydrothiopyrano[2,3d] $(1,3)$ thiazol-6-yl)acetic acid ethanol solvate. Acta Cryst Section E. 2012;68:2721-2723.

15. Lesyk R, Zimenkovsky B, Atamanyuk D, Jensen F, Kieć-Kononowicz K, Gzella A. Anticancer thiopyrano[2,3-d][1,3] thiazol-2-ones with norbornane moiety. Synthesis, cytotoxicity, physico-chemical properties, and computational studies. Bioorg Med Chem. 2006;14(15):5230-5240.

16. Atamanyuk D, Zimenkovsky B, Lesyk R. Synthesis and anticancer activity of novel thiopyrano[2.3-d] thiazole-based compounds containing norbornane moiety. J Sulf Chem. 2008;29:151-162.

17. Kaminskyy D, Vasylenko O, Atamanyuk D, Gzella A, Lesyk $R$. Isorhodanine and thiorhodanine motifs in the synthesis of fused thiopyrano [2,3-d][1,3]thiazoles. Synlett. 2011;10:1385-1388. 
18. Kryshchyshyn A, Atamanyuk D, Lesyk R. Fused thiopyrano[2,3-d]thiazole derivatives as potential anticancer agents. Sci Pharm. 2012;80:509-529.

19. Lozynskyi A, Zimenkovsky B, Lesyk R. Synthesis and anticancer activity of new thiopyrano[2,3-d]thiazoles based on cinnamic acid amides. Sci Pharm. 2014;82:723-733.

20. Zelisko N, Atamanyuk D, Vasylenko O, Grellier P, Lesyk $R$. Synthesis and antitrypanosomal activity of new 6.6.7-trisubstituted thiopyrano[2,3-d][1,3]thiazoles. Bioorg Med Chem Lett. 2012;22:7071-7074.

21. Atamanyuk D, Zimenkovsky B, Atamanyuk V, Nektegayev I, Lesyk $R$. Synthesis and biological activity of new thiopyrano[2,3-d]thiazoles containing a naphthoquinone moiety. Sci Pharm. 2013;81:423436.

22. Zelisko N, Karpenko O, Muzychenko V, Gzella A, Grellier Ph, Lesyk R. Trans-aconitic acid-based hetero-Diels-Alder reaction in the synthesis of thiopyrano[2,3-d][1,3]thiazole derivatives. Tetrahedron Lett. 2017;58:1751-1754.

23. Lozynskyi A, Golota S, Zimenkovsky B, Atamanyuk $D$, Gzella A, Lesyk $R$. Synthesis, anticancer and antiviral activities of novel thiopyrano[2,3-d] thiazole-6-carbaldehydes. Phosphorus Sulfur Silicon Relat Elem. 2016;191:1245-1249.

24. Liu X, Zu YG, Fu YJ, Yao LP, Gu CB, Wang W, Efferth $T$. Antimicrobial activity and cytotoxicity towards cancer cells of Melaleuca alternifolia (tea tree) oil. Eur Food Res Technol. 2009;229:247-253.

25. Havrylyuk D, Zimenkovsky B, Vasylenko O, Gzella $A$, Lesyk $R$. Synthesis of new 4-thiazolidinone, pyrazoline, and isatin-based conjugates with promising antitumor activity. J Med Chem. 2012;55:86308641.

\section{Скринінг спіро-заміщених тіопірано[2,3-d] тіазолів щодо їх цитотоксичної дії на пухлинні клітини}

Н. І. Зеліско, Н. С. Фінюк, В. М. Швець, Ю. О. Медвідь, Р. С. Стойка, Р. Б. Лесик

Мета. Вивчення цитотоксичної активності нових спіро-заміщених похідних тіопірано[2,3- $d]$ тіазолу на пухлинні клітин різного походження. Методи. Органічний синтез; спектральні методи; МТТ тест, статистичний аналіз. Результати. Проведено дослідження in vitro 5'-карбокси-7'-арил-1-арил-3',7'-дигідро- $2 \mathrm{H}, 2$ ' $H, 5 \mathrm{H}$ спіро[піролідин-3,6'-тіопірано[2,3-d]тіазол]-2,2',5тріонів і $N$-(4-хлорофеніл)-2-[1-(4-хлорофеніл)-2,5діоксопіролідин-3-іліден]-ацетаміду щодо різних ліній пухлинних клітин (Т-клітинної лейкемії Jurkat, аденокарциноми молочної залози МСF-7, карциноми яєчника Skov3, меланоми SK-Mel-28, недрібноклітинного раку легені SW-1573). Синтезовані сполуки мають різну цитотоксичну дію щодо використаних ліній пухлинних клітин. Клітини лейкемії виявилися найбільш чутливими до дії цих похідних. Цитотоксичний ефект сполуки 2 щодо Т-клітинної лейкеміï Jurkat залежить від дози сполуки і тривалості ії дії (3, 6, 24, 48 і 72 год). Сполука 2 володіє цитотоксичною дією на лейкемічні клітини лінії Jurkat вже через 6 год після іiі додавання до культури цих клітин $\left(\mathrm{IC}_{50}=66 \mu \mathrm{M}\right)$, а через 24 год ії цитотоксичність зростас $\left(\mathrm{IC}_{50}=40 \mu \mathrm{M}\right)$. Висновки. Проведено скринінг нових спіро-заміщених похідних тіопірано[2,3- $d$ ]тіазолу щодо їх цитотоксичної дії на пухлинні клітини in vitro. Сполука 2 володіє найвищою активністю у лейкемічних Т-клітинах лінії Jurkat $\left(\mathrm{IC}_{50}=33,5\right.$ мкM), тоді як іiі токсичність щодо псевдо-нормальних клітин ссавців $є$ відносно низькою.

К л юч о в і с л о в а: тіопірано[2,3- $d]$ тіазоли, протипухлинна активність

\section{Скрининг спиро-замещенных тиопирано[2,3-d] тиазолов относительно их цитотоксического действия на опухолевые клетки}

Н. И. Зелиско, Н. С. Финюк, В. Н. Швець, Ю. О. Медвидь, Р. С. Стойка, Р. Б. Лесык

Цель. Изучение цитотоксической активности новых спиро-замещенных производных тиопирано[2,3-d] тиазола на опухолевые клетки различной этиологии. Методы. Органический синтез; спектральные методы; MTT тест, статистический анализ. Результаты. Исследовано действие 5'-карбокси-7'-арил-1-арил3', 7'-дигидро-2H,2 ' тиопирано[2,3-d]тиазол]-2,2',5-трионов и $N$-(4х лор о фени л ) - 2 - [ 1 - ( 4 - хл о р о фен ил ) - 2, 5 диоксопиролидин-3-илиден]-ацетамида на опухолевым клеткам (Т-клеточной лейкемии Jurkat, аденокарциномы 
молочной железы MCF-7, карциномы яичника Skov3, меланомы SK-Mel-28, немелкоклеточного рака легких SW-1573) in vitro. Синтезируемые соединения имеют различное цитотоксическое действие по отношению к используемых линий опухолевых клеток. Клетки лейкемии оказались наиболее чувствительными к этим производным. Цитотоксический эффект соединения $\mathbf{2}$ относительно Т-клеточной лейкемии Jurkat зависит від дозы соединения і продолжительности ее действия (3, 6, 24, 48 і 72 год). (3, 6, 24, 48 и 72 ч). Соединение 2 обладает цитотоксическим на лейкемические клетки линии Jurkat уже через 6 ч после ее добавления к культуре этих клеток $\left(\mathrm{IC}_{50}=66\right.$ мкM), а через 24 часа ее цитотоксичность увеличивается $\left(\mathrm{IC}_{50}=40\right.$ мкM). Выводы. Определено цитотоксического действия новых спиро-замещенных производных тиопирано[2,3- $d$ ] тиазола на опухолевые клетки in vitro. Соединение 2 обладает наивысшей активностью на лейкемические T-клеточные линии Jurkat $\left(\mathrm{IC}_{50}=33,5\right.$ мкM), в тоже время ее токсичность на псевдо-нормальных клетках млекопитающих была относительно невысокой.

К л юч е в ы е с л о в а: тиопирано[2,3- $d]$ тиазолы, противоопухолевая активность.

Received 24.04.2017 